\title{
$\beta$-Amyloid Inhibits Protein Prenylation and Induces Cholesterol Sequestration by Impairing SREBP-2 Cleavage
}

\author{
Amany Mohamed, Lucila Saavedra, Alba Di Pardo, Simonetta Sipione, and Elena Posse de Chaves \\ Department of Pharmacology, University of Alberta, Edmonton, Alberta, Canada T6G 2H7
}

Accumulation of $\beta$-amyloid $(\mathrm{A} \beta)$ inside brain neurons is an early and crucial event in Alzheimer's disease (AD). Studies in brains of AD patients and mice models of $\mathrm{AD}$ suggested that cholesterol homeostasis is altered in neurons that accumulate $\mathrm{A} \beta$. Here we directly investigated the role of intracellular oligomeric $\mathrm{A} \beta_{42}\left(\mathrm{oA} \beta_{42}\right)$ in neuronal cholesterol homeostasis. We report that $\mathrm{oA} \beta_{42}$ induces cholesterol sequestration without increasing cellular cholesterol mass. Several features of $A D$, such as endosomal abnormalities, brain accumulation of $A \beta$ and neurofibrillary tangles, and influence of apolipoprotein $\mathrm{E}$ genotype, are also present in Niemann-Pick type $\mathrm{C}$, a disease characterized by impairment of intracellular cholesterol trafficking. These common features and data presented here suggest that a pathological mechanism involving abnormal cholesterol trafficking could take place in AD. Cholesterol sequestration in A $\beta$-treated neurons results from impairment of intracellular cholesterol trafficking secondary to inhibition of protein prenylation. $\mathrm{oA} \beta_{42}$ reduces sterol regulatory element-binding protein-2 (SREBP-2) cleavage, causing decrease of protein prenylation. Inhibition of protein prenylation represents a mechanism of $\mathrm{oA} \beta_{42}$-induced neuronal death. Supply of the isoprenoid geranylgeranyl pyrophosphate to $\mathrm{oA} \beta_{42}$-treated neurons recovers normal protein prenylation, reduces cholesterol sequestration, and prevents $\mathrm{A} \beta$-induced neurotoxicity. Significant to $\mathrm{AD}$, reduced levels of protein prenylation are present in the cerebral cortex of the TgCRND 8 mouse model. In conclusion, we demonstrate a significant inhibitory effect of $A \beta$ on protein prenylation and identify SREBP- 2 as a target of $\mathrm{oA} \beta_{42}$, directly linking $\mathrm{A} \beta$ to cholesterol homeostasis impairment.

\section{Introduction}

Alzheimer's disease (AD), the most common form of age-related dementia, is characterized by accumulation of $\beta$-amyloid peptide $(\mathrm{A} \beta)$ and neurofibrillary tangles in the brain (Selkoe, 2004). Intraneuronal accumulation of $\mathrm{A} \beta$ precedes neurofibrillary tangles and $\mathrm{A} \beta$ plaques deposition (D'Andrea et al., 2001; Wirths et al., 2002 ) and has been causally linked to cell death (LaFerla et al., 1995; Chui et al., 2001; Zhang et al., 2002; Blanchard et al., 2003; Casas et al., 2004; Christensen et al., 2008, 2010; Tomiyama et al., 2010), synaptic dysfunction (Takahashi et al., 2002; Oddo et al., 2003), and cognitive impairment (Billings et al., 2005). $\mathrm{A} \beta_{42}$ is degraded poorly inside neurons and accumulates in vesicles identified as lysosomes or late endosomes/multivesicular bodies (MVBs) (D'Andrea et al., 2001; Ditaranto et al., 2001; Takahashi et al., 2002; Langui et al., 2004). A $\beta$ accumulation in the endocytic pathway causes endosomal alterations characteristic of $\mathrm{AD}$ (Nixon, 2005). These endosomal abnormalities are similar to

Received Feb. 9, 2012; revised March 15, 2012; accepted March 16, 2012.

Author contributions: A.M. and E.P.d.C. designed research; A.M. and L.S. performed research; A.D., S.S., and E.P.d.C. contributed unpublished reagents/analytic tools; A.M., L.S., A.D., S.S., and E.P.d.C. analyzed data; A.M. and E.P.d.C. wrote the paper.

This work was supported by grants from the Canadian Institutes of Health Research and the Alzheimer Society of Canada. We thank Dr. S. Kar (University of Alberta, Edmonton, AB, Canada) for providing mice brains, Dr. J. Gruenberg (University of Geneva, Geneva, Switzerland) for providing the GDI-GST plasmid, and Dr. K. Ko (University of Alberta) for helping in expression and purification of GST-GDI. We also thank B. Khaniya and A. Leung for technical support.

The authors declare no competing financial interests.

Correspondence should be addressed to Elena Posse de Chaves, Department of Pharmacology, 9-31 Medical Sciences Building, Edmonton, AB, Canada, T6G 2H7. E-mail: elena.chaves@ualberta.ca.

DOI:10.1523/JNEUROSCI.0630-12.2012

Copyright $\odot 2012$ the authors $\quad 0270-6474 / 12 / 326490-11 \$ 15.00 / 0$ those observed in patients with Niemann-Pick type C disease (NPC), a disorder characterized by impairment of intracellular cholesterol trafficking (Yamazaki et al., 2001; Runz et al., 2002; Saito et al., 2002; Jin et al., 2004; Nixon, 2005; Koh and Cheung, 2006). NPC and AD share other features. Inhibition of intracellular cholesterol transport increases amyloidogeneic cleavage of amyloid precursor protein (APP) and $\mathrm{A} \beta$ production in animal models of NPC and in neurons treated with U18666A (3- $\beta$-[2(diethylamino)ethoxy]androst-5-en-17-one), a chemical agent that induces cholesterol sequestration and mimics some aspects of the NPC phenotype (Runz et al., 2002). Conversely, studies in human $\mathrm{AD}$ brains have shown cholesterol or cholesterol esters accumulation specifically in $\mathrm{A} \beta$-immunopositive neurons ( $\mathrm{Ohm}$ et al., 2003; Gómez-Ramos and Asunción Morán, 2007; Xiong et al., 2008). In the AD mouse model APP/PS1, brain cholesterol accumulation was preceded by $A \beta$ accumulation, suggesting that $\mathrm{A} \beta$ could regulate cholesterol homeostasis and/or trafficking (Fernández et al., 2009). We have undertaken this study to examine the effects of $A \beta$ accumulation on neuronal cholesterol homeostasis. Here we report that oligomeric $\mathrm{A} \beta_{42}\left(\mathrm{oA} \beta_{42}\right)$ causes cholesterol sequestration within primary neurons. Cholesterol accumulation is secondary to decreased protein prenylation and reduced intracellular trafficking. The inhibition of protein prenylation is also a mechanism of $\mathrm{oA} \beta_{42}$ neurotoxicity and can be prevented by replenishing the neuronal pool of isoprenoids.

\section{Materials and Methods}

Reagents. $\mathrm{A} \beta_{42}$ was purchased from American Peptide. The same lot number was used throughout this study. Reverse $\mathrm{A} \beta_{42}\left(\operatorname{revA} \beta_{42}\right)$ was obtained from Alpha Diagnostic. Leibovitz L-15- $\mathrm{CO}_{2}$ culture medium was from Invitrogen. Mouse NGF $(2.5 \mathrm{~S})$ was purchased from Alomone 
Labs. EZ-Link NHS-S-S-biotin and ImmunoPure immobilized Streptavidin were purchased from Pierce. Amplex Red cholesterol assay kit was from Invitrogen. Immobilon polyvinylidene difluoride (PVDF) was from Bio-Rad. Enhanced chemiluminescence reagents were from GE Healthcare. U18666A was purchased Biomol. Geranylgeranyl pyrophosphate (GGPP) was from Sigma-Aldrich and $\left[{ }^{3} \mathrm{H}\right]$ GGPP from PerkinElmer Life and Analytical Sciences. Filipin, methyl $\beta$ cyclodextrin, heptane, and diisopropylether were purchased from Sigma. GGTI-2133 (4-[[N(Imidazol-4-yl)methyleneamino]-2-(1-naphthyl)benzoyl]leucine) was obtained from Calbiochem. All other reagents were from Thermo Fisher Scientific.

Culture of neurons. Rat basal forebrain and sympathetic neurons were prepared and cultured as described previously (Saavedra et al., 2007). Basal forebrain cholinergic neurons were isolated from brains of E17E18 Sprague Dawley rats of either sex (Health Science Lab Animal Services, University of Alberta, Edmonton, AB, Canada) by enzymatic dissociation with $0.1 \% \mathrm{w} / \mathrm{v}$ of trypsin for $15 \mathrm{~min}$ and plated in poly-Dlysine-coated plates in Neurobasal medium supplemented with MEM, HEPES, penicillin/streptomycin/L-glutamine, and B27. Sympathetic neurons isolated from superior cervical ganglia of newborn Harlan Sprague Dawley rats of either sex (Health Science Lab Animal Services, University of Alberta) were prepared by enzymatic dissociation with $1 \%$ $(\mathrm{w} / \mathrm{v})$ of collagenase and $0.1 \%(\mathrm{w} / \mathrm{v})$ of trypsin followed by mechanical dissociation using a flame-polished Pasteur pipette. After filtration of the cell suspension through cell strainer (40 $\mu \mathrm{m}$ nylon; Falcon), neurons were plated. Standard culture medium was $\mathrm{L}-15-\mathrm{CO}_{2}$ supplemented with $0.4 \%$ methylcellulose. Non-neuronal cells were eliminated with $10-15 \mu \mathrm{M}$ cytosine arabinoside during the first 5-6 d in culture. Two types of neuronal cultures were used: mass cultures and compartmented cultures. For mass cultures, neurons were plated in 24-well dishes at a density of 1-2 ganglia per well in medium supplemented with $2.5 \%$ rat serum, $1 \mathrm{mg} / \mathrm{ml}$ ascorbic acid, and $50 \mathrm{ng} / \mathrm{ml} \mathrm{NGF}$. Alternatively, sympathetic neurons were cultured in three-compartment culture dishes as described previously (Saavedra et al., 2007). Briefly, dissociated neurons were plated in the center compartment at a density of 0.2 ganglia per dish in medium containing $2.5 \%$ rat serum, $1 \mathrm{mg} / \mathrm{ml}$ ascorbic acid, $10-15 \mu \mathrm{M}$ cytosine arabinoside, and $10 \mathrm{ng} / \mathrm{ml} \mathrm{NGF}$. After 5-6 d, cytosine arabinoside treatment was discontinued, and NGF $(50 \mathrm{ng} / \mathrm{ml})$ was confined to the side compartments. All experiments started at day 7-8 in culture. Rat cortical neurons were prepared according to Brewer and Torricelli (2007).

$o A \beta_{42}$ preparation. oA $\beta_{42}$ was prepared following a published protocol (Dahlgren et al., 2002). A $\beta$ peptide was initially dissolved to $1 \mathrm{~mm}$ in hexafluoroisopropanol and separated into aliquots in sterile microcentrifuge tubes. Hexafluoroisopropanol was dried under a stream of N2, and the peptide film was desiccated at $-20^{\circ} \mathrm{C}$. The peptide was resuspended in $\mathrm{Me}_{2} \mathrm{SO}$ at a concentration of $5 \mathrm{~mm}$. L-15- $\mathrm{CO}_{2}$ medium (phenol red-free, antibiotic-free, and serum-free) was added to bring the peptide to a final concentration of $100 \mu \mathrm{M}$ and incubated at $4^{\circ} \mathrm{C}$ for $24 \mathrm{~h}$. All $\mathrm{oA} \beta_{42}$ preparations used were similar to those characterized previously (Dahlgren et al., 2002; Saavedra et al., 2007) in that they contain monomers and oligomers of $\mathrm{A} \beta$ but do not contain fibrils. The neurotoxic ability of these $\mathrm{A} \beta$ preparations toward primary neurons has been characterized previously (Song et al., 2006).

Immunofluorescence and confocal microscopy. For confocal microscopy studies, neurons were fixed with $4 \%$ paraformaldehyde for $20 \mathrm{~min}$ at room temperature, permeabilized with $0.3 \%$ saponin for $15 \mathrm{~min}$ at room temperature, and blocked by incubation with $2 \%$ bovine serum albumin for $1 \mathrm{~h}$ on ice. Primary antibodies were prepared in the same blocking solution. Primary antibodies used include the following: anti-lamp1 (sc8098; Santa Cruz Biotechnology) at 1:100, anti-EEAl (sc-33585; Santa Cruz Biotechnology) at 1:100, anti-COX-IV (ab14744; Abcam) at 1:400, and anti-giantin (a generous gift from Dr. Hobman, University of Alberta) at 1:300. Incubation was performed overnight at $4^{\circ} \mathrm{C}$. Secondary antibodies (Alexa Fluor 594-labeled or Alexa Fluor 488-labeled antimouse or anti-rabbit) prepared in blocking buffer (1:1000) were incubated for $2 \mathrm{~h}$ at room temperature. For filipin staining, fixed neurons were incubated with $100 \mu \mathrm{g} / \mathrm{ml}$ filipin (Sigma) at room temperature for $2 \mathrm{~h}$. Nuclei were stained with Draq5 (Biostatus Limited) at 1:4000. Pic- tures were taken using a laser scanning confocal microscope Carl Zeiss LSM 710 equipped with an S-Fluor $40 \times / 1.3 \mathrm{NA}$ oil-immersion objective using appropriate filter sets and excitation wavelengths. Within an experiment, all pictures were taken with the same setting for a particular fluorophore. If required for printing purposes, brightness and contrast were adjusted using Photoshop software (Adobe Systems). All images were adjusted with the same parameters. The pictures selected are representative of at least three separate experiments performed under identical conditions.

Cholesterol mass. Cholesterol mass from cultured neurons was measured using the enzymatic Amplex red cholesterol assay kit or by gas chromatography (Lipid and Lipid Metabolite Analysis Core Facility, University of Alberta). Results obtained by the two methods were identical.

Cholesterol synthesis. Cholesterol synthesis was determined by measuring incorporation of $\left[{ }^{3} \mathrm{H}\right]$ acetate using methods described by de Chaves et al. (1997) and modified as described herein. Neurons received the treatment indicated in each case with the addition of the radioactive cholesterol precursor $\left[1-{ }^{3} \mathrm{H}\right]$ acetic acid $(100 \mu \mathrm{Ci} / \mathrm{ml})$ for the last $2 \mathrm{~h}$. The radioactive medium was removed, neurons were washed twice with cold PBS, and cellular material was harvested and sonicated. An aliquot was separated for protein determination. A second aliquot was used for lipid isolation and quantification. Lipids were isolated from the cell lysate according to the method of Folch (Folch et al., 1959) with chloroform/ methanol/water ratio of 2:1:1 (v/v). Individual lipid separation was accomplished by thin-layer chromatography (TLC). TLC plates were developed in the solvent system heptane/isopropyl ether/acetic acid (60: 40:4, v/v) using unlabeled cholesterol as carrier. The band corresponding to authentic unesterified cholesterol was scraped from the plate, and radioactivity was measured. Radioactivity was normalized to protein mass and expressed in disintegration per minute $(\mathrm{dpm})$ per micrograms protein. At least four cultures per treatment were used. To combine three or more experiments, the results were expressed compared with the untreated neurons, which were given a value of $100 \%$.

Cholesterol trafficking. Neurons were cultured in compartmented dishes. $\left[{ }^{3} \mathrm{H}\right]$ Acetate at $150 \mu \mathrm{Ci} / \mathrm{ml}$ was added to the cell-body-containing compartment for the last $24 \mathrm{~h}$ of treatment. After rinsing, the cellular material of the cell-body-containing compartment and the distal-axoncontaining compartment was harvested separately. Lipid were extracted and separated by TLC as indicated above. Radioactivity of $\left[{ }^{3} \mathrm{H}\right]$ cholesterol was expressed as \% (total) $=\mathrm{dpm}$ in cell bodies or distal axons/ (dpm in cell bodies $+\mathrm{dpm}$ in distal axons).

Immunoblot analysis. Proteins were separated by SDS-PAGE using gels at 10 or $12 \%$ containing $0.1 \%$ SDS. Transfer of proteins to PVDF membranes was performed overnight at $4^{\circ} \mathrm{C}$ in $25 \mathrm{~mm}$ Tris, $192 \mathrm{~mm}$ glycine, and $16 \%$ methanol buffer, $\mathrm{pH}$ 8.3. Membranes were blocked for $1 \mathrm{~h}$ in Tris-buffered saline, $0.1 \%$ Tween 20 (TTBS) containing 5\% nonfat milk (blocking buffer) and incubated overnight in the primary antibody solution prepared in TTBS containing 5\% nonfat milk. Primary antibodies for $\beta$-actin (catalog \#4967, 1:1000; Cell Signaling Technology), sterol regulatory element-binding protein-2 (SREBP-2) (ab-30682,1:500; Abcam), $\beta$-tubulin (T4026, 1:200; Sigma), Ras (catalog \#05-516, 1:500; Millipore), Flotillin-1 (catalog \#610821, 1:1000; BD Transduction Labs), Rab7 (catalog \#R8779, 1:1000; Sigma), and Rab9 (ab2810, 1:500; Abcam) were used. Membranes were washed two times with Tris-buffered saline, two times with TTBS, and two times with Tris-buffered saline and then incubated for $1 \mathrm{~h}$ with the secondary antibody (1:2000) in blocking buffer at room temperature with gentle agitation. Immunoreactivity was detected by ECL Plus Western Blotting detection system (GE Healthcare). UN-SCAN-IT gel 5.3 software was used for semiquantification of the bands on immunoblots.

Biotinylation and retrograde transport of NGF receptor TrkA. Surface axonal proteins were biotinylated by incubation with $1.5 \mathrm{mg} / \mathrm{ml}$ of the membrane-impermeable derivative of biotin (sulfo-NHS-S-S-biotin) (Pierce) in Leibovitz L-15- $\mathrm{CO}_{2}$ medium (free of NGF, phenol red, antibiotics, and serum) for $20 \mathrm{~min}$ at $4^{\circ} \mathrm{C}$, in the side compartments of neurons cultured in compartmented dishes. Remaining reactive biotin reagent was quenched by incubating cells with $50 \mathrm{~mm}$ glycine in modified PBS twice each for $10 \mathrm{~min}$ at $4^{\circ} \mathrm{C}$. Immediately after, fresh medium 
containing NGF without or with $20 \mu \mathrm{M} \mathrm{oA} \beta_{1-42}$ was added to the axons, and neurons were incubated under regular conditions for 6 and $18 \mathrm{~h}$. NGF induces TrkA activation, endocytosis, and retrograde transport. The cellular material from cell-body-containing compartment and distal-axon-containing compartments was collected separately (two dishes were pooled) and lysed in modified RIPA buffer ( $1 \%$ Triton $\mathrm{X}-100,0.1 \%$ SDS, $0.5 \%$ deoxycholic acid, $50 \mathrm{~mm}$ Tris- $\mathrm{HCl}, 100 \mathrm{~mm} \mathrm{NaCl}$, 1 mм EDTA, 2 mм EGTA, $50 \mathrm{~mm}$ NaF, $10 \mathrm{~mm}$ sodium pyrophosphate, and $1 \mathrm{~mm}$ sodium orthovanadate, $\mathrm{pH} 7.4$, with protease inhibitor mixture) at $4^{\circ} \mathrm{C}$ for $30 \mathrm{~min}$. The lysate was centrifuged at $16,000 \times \mathrm{g}$ for 15 $\min$ at $4^{\circ} \mathrm{C}$, and the resulting supernatants were incubated with $40 \mu \mathrm{l}$ of $50 \%$ Streptavidin agarose beads (Pierce) overnight at $4^{\circ} \mathrm{C}$. The beads were then washed three times with modified RIPA buffer, and the bound proteins were eluted with SDS sample buffer containing dithiothreitol (50 mu final concentration) boiling for $5 \mathrm{~min}$. Biotinylated proteins were separated by SDS-PAGE using $8 \%$ gels. Immunoblot analysis of TrkA was performed as described previously (Song et al., 2006). In all cases, the supernatants of incubation with Streptavidin agarose beads were examined by SDS-PAGE, protein transfer to PDVF membrane, and biotinylated protein detection with Streptavidin linked to horseradish peroxidase and ECL to ensure the complete binding of biotinylated proteins to the beads.

Preparation of membrane and cytosol fractions from cultured neurons. Neurons were harvested in $10 \mathrm{~mm}$ HEPES, pH 7.6, containing $250 \mathrm{~mm}$ sucrose, $10 \mathrm{~mm} \mathrm{KCl}, 1.5 \mathrm{~mm} \mathrm{MgCl}_{2}, 1 \mathrm{~mm}$ EDTA, $1 \mathrm{~mm}$ EGTA and protease inhibitor cocktail, $1 \mathrm{~mm} \mathrm{NaF}$, and $2 \mathrm{~mm} \mathrm{NaVO}_{4}$. Cellular material was homogenized by passing 20 times through a 25 gauge needle. After resting $20 \mathrm{~min}$ on ice, the cell homogenate was centrifuged at $1000 \times g$ for $10 \mathrm{~min}$ at $4^{\circ} \mathrm{C}$ to eliminate unbroken cells and cellular debris. Protein content of the supernatant was determined (BCA; Pierce) and equal amounts of protein from each treatment were centrifuged at $105,000 \times g$ for $1 \mathrm{~h}$ at $4^{\circ} \mathrm{C}$ in a Beckman Coulter Optima MAX-XP Utracentrifuge using the MLA-130 fixed-angle rotor. Supernatants (cytosol fractions) and the pellets (membrane fractions) were separated.

Preparation of membrane and cytosol fractions from mice brains. Frontal cortices from 10-week-old male wild-type and TgCRND8 mice were cut in small pieces and homogenized in the same buffer used for membrane/ cytosol separation from cultured neurons by passing through a 22 gauge needle 15 times. After $20 \mathrm{~min}$ on ice, the homogenate was cleared by centrifugation at $1000 \times g$ for $10 \mathrm{~min}$ at $4^{\circ} \mathrm{C}$. The supernatant was centrifuged at $105,000 \times g$ for $1 \mathrm{~h}$ at $4^{\circ} \mathrm{C}$ in a Beckman Coulter Optima MAX-XP Utracentrifuge using the MLA-130 fixed-angle rotor. The supernatant of this is the cytosol fraction, and the pellet represents the membrane fraction.

Protein prenylation. Protein prenylation was examined by extraction of prenylated proteins with Triton X-114 or recombinant GDP dissociating inhibitors fused to glutathione $S$-transferase (GST-GDI).

Separation of prenylated and unprenylated Rab using Triton X-114. The proportion of prenylated and unprenylated Rabs were examined using Triton X-114 according to Coxon et al. (2005). Two-phase mixtures of Triton X-114 were formed at $37^{\circ} \mathrm{C}$ so that lipophilic, prenylated Rabs partition into the detergent-rich phase, whereas unprenylated Rabs remain in the aqueous phase. For experiments with cultured neurons, neurons were harvested at the end of the corresponding treatments in Tris buffer containing Triton X-114 (20 mm Tris-HCl, pH 7.5, containing $150 \mathrm{~mm} \mathrm{NaCl}, 1 \%$ Triton X-114, and protease inhibitor cocktail) and incubated for $15-20 \mathrm{~min}$ at $4^{\circ} \mathrm{C}$. Lysates were cleared by centrifugation at $13,000 \times g$ for $15 \mathrm{~min}$ at $4^{\circ} \mathrm{C}$. Protein content was determined in the clear supernatants. For experiments in mice brains, frontal cortices from 10week-old wild-type and APP-Tg (TgCRND8) mice were lysed separately with Triton X-114 as for cultured neurons. In all cases, equal amounts of proteins were adjusted to the same volume with Tris buffer containing Triton X-114, were loaded on top of a cushion solution (20 mM Tris- $\mathrm{HCl}$, $\mathrm{pH} 7.4$, containing $150 \mathrm{~mm} \mathrm{NaCl}, 6 \%$ sucrose, $0.06 \%$ Triton X-114, and protease inhibitor cocktail) and were incubated at $37^{\circ} \mathrm{C}$ for $10 \mathrm{~min}$. After centrifugation at $16,000 \times g$ for $5 \mathrm{~min}$, the top aqueous clear layer was separated from the detergent-rich, oil-like droplet. Both layers were boiled with SDS sample buffer, and proteins were resolved by $12 \%$ SDSPAGE. Immunoblot analysis was performed with anti-Rab9 (ab-2810,
1:500; Abcam) and/or anti-Rab7 (R8779, 1:1000; Sigma). Notice that prenylated Rabs always run faster than unprenylated Rabs under our experimental SDS-PAGE conditions. The lower band is present in the detergent phase.

Rab-GDI capture. GDI capture was performed according to Narita et al. (2005). Neuronal lysates were prepared by homogenization of cultured neurons in buffer containing $250 \mathrm{~mm}$ sucrose, $3 \mathrm{~mm}$ imidazole, $\mathrm{pH}$ 7.4, with $1 \mathrm{~mm}$ DTT and protease inhibitors by passing through a 22 gauge needle 10 times on ice, followed by centrifugation at $300 \times g$ for 5 min to eliminate unbroken cells and cellular debris. Alternatively cytosol and membranes fractions from neuronal cultures or mice brains prepared as indicated above were used. Protein content was measured, and equal amounts of proteins from all samples were diluted fivefold with extraction buffer (30 mM HEPES, $75 \mathrm{~mm}$ potassium acetate, $5 \mathrm{~mm} \mathrm{MgCl}_{2}$, $100 \mu \mathrm{M}$ ATP, and $500 \mu \mathrm{M}$ GDP) containing $10 \mu \mathrm{M}$ GDI-GST and incubated for $20 \mathrm{~min}$ at $30^{\circ} \mathrm{C}$. Rabs bound to GDI were recovered by incubating with glutathione-Sepharose $4 \mathrm{~B}$ beads (GE Healthcare), eluted by boiling with SDS-sample buffer for $10 \mathrm{~min}$, and analyzed by SDS-PAGE and immunoblotting with anti Rab7 or anti Rab9 antibodies. As indicated for Triton X-114 extraction, prenylated Rabs ran faster than unprenylated Rabs. The lower band is the only band present in membrane preparations, as is the band that binds to GDI.

Incorporation of exogenous GGPP in prenylated proteins. Neurons were treated with $20 \mu \mathrm{M} \mathrm{oA} \beta_{42}$ or $50 \mu \mathrm{M}$ pravastatin. [ ${ }^{3} \mathrm{H}$ ] GGPP $(22.4 \mathrm{Ci} /$ $\mathrm{mmol}$ ) was added at a concentration of $200 \mu \mathrm{Ci} / \mathrm{ml}(9.1 \mu \mathrm{M})$. After $24 \mathrm{~h}$, neurons were rinsed several times, harvested, and lysed. Radioactivity was counted in an aliquot of the neuronal lysate and was used to calculate GGPP uptake. Proteins in neuronal lysates were separated and identified by SDS-PAGE and immunoblotting for Rab7 and actin. PDVF membranes were dyed with Ponceau Red, and bands corresponding to the molecular weight of Rab7 were cut for radioactivity counting. Radioactivity of the rest of the lane was counted separately. The results were referred to actin content and expressed in disintegration per minute in Rabs/actin pixels or total protein disintegration per minute/actin pixels.

Evaluation of metabolic activity. Metabolic activity was evaluated using the cell 3-(4,5-dimethylthiozolyl)-2,5-diphenyltetrazolium bromide (MTT) reduction assay (Promega). This assay is based on the conversion of MTT to a blue/purple formazan crystal by reduced or phosphorylated nicotinamide adenine dinucleotide (NADH or NADPH) produced by dehydrogenase enzymes in metabolically active cells (Berridge and Tan, 1993). After neuron treatment, MTT was added to the medium, and incubation continued for $1 \mathrm{~h}$ in $\mathrm{CO}_{2}$ incubator at $37^{\circ} \mathrm{C}$. The blue formazan product of MTT reduction was visualized under the microscope. Direct observation of decreased color formation in bright-field images is indicative of decreased metabolic activity.

Statistical analysis. Prism 4 computer software (GraphPad Software) was used. Data were from three to five experiments with three to five determinations each. Values were expressed as means \pm SE. Statistical significance was analyzed using one-way ANOVA Kruskal-Wallis statistic with Dunn's multiple comparison test and is indicated $\left({ }^{*} p<0.05\right.$, ${ }^{\star *} p<0.01$, or $\left.{ }^{\star * *} p<0.001\right)$. In experiments with only two groups, $t$ test was used.

\section{Results}

$A \boldsymbol{\beta}_{42}$ causes intracellular accumulation of endogenous cholesterol

Because of poor degradation, $A \beta_{42}$ accumulates inside neurons with dramatic consequences. We observed that, in neurons exposed to toxic concentrations of oA $\beta_{42}$, there was extensive accumulation of unesterified cholesterol as detected by filipin staining (Fig. 1A). This effect was specific to $\mathrm{oA} \beta_{42}$ because $\operatorname{revA} \beta_{42}$ did not induce cholesterol accumulation (Fig. $1 A$ ). The pattern of cholesterol staining with filipin in oA $\beta_{42}$-treated neurons resembled, but was not identical to that displayed by neurons treated with the amphiphilic amine U18666A, conventionally used to mimic the accumulation of cholesterol characteristic of NPC phenotype (Karten et al., 2002). Cholesterol significantly colocalized with LAMP1, a marker for MVBs/lyso- 

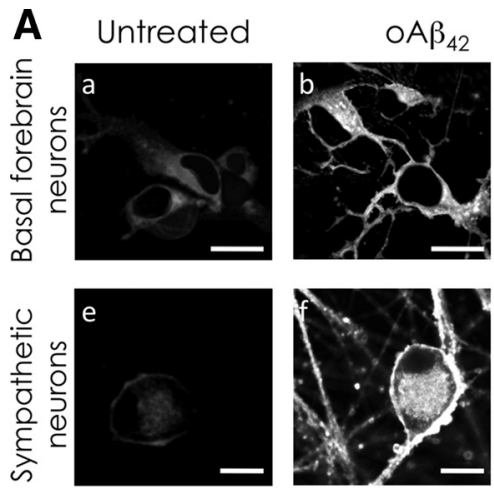

B

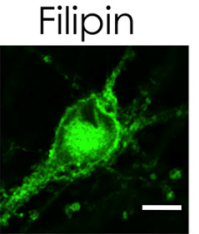

Filipin
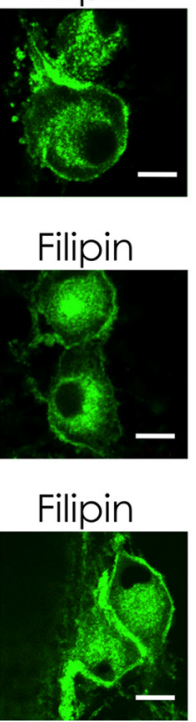

LAMP 1
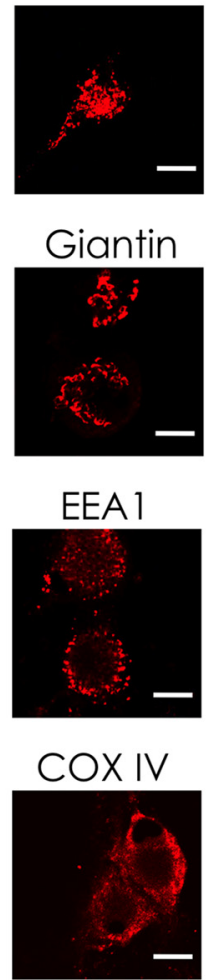

Merged

Merged

Merged
$\operatorname{revA} \beta_{42}$
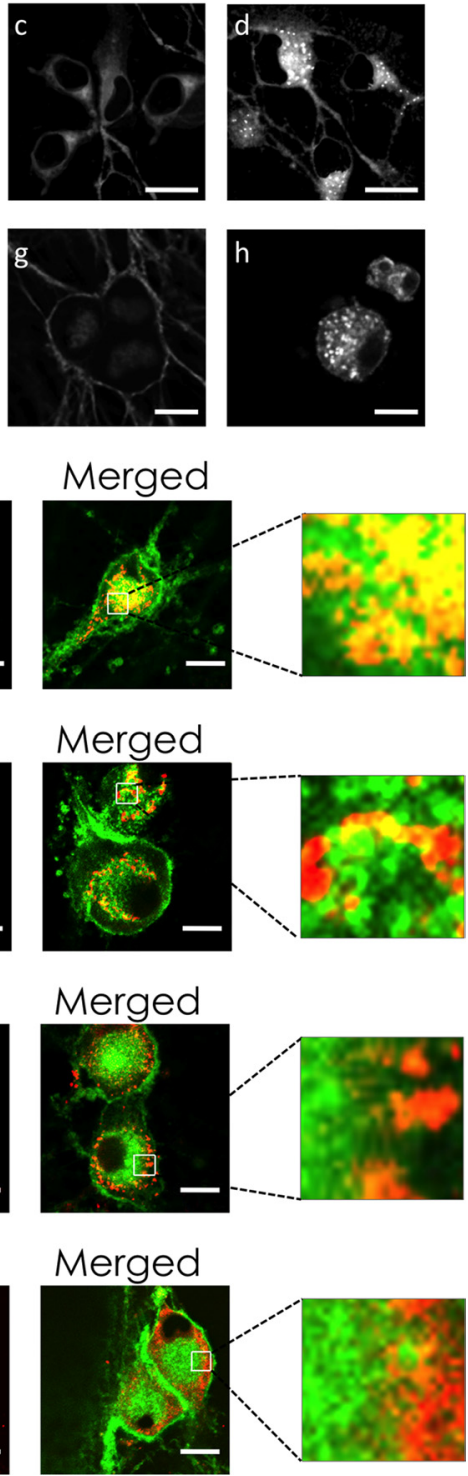

U18666A
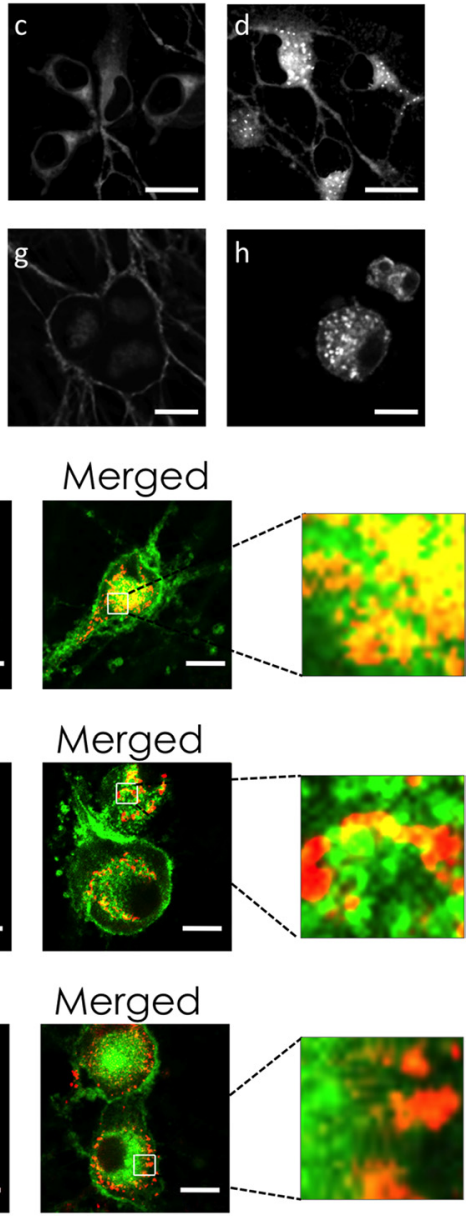

Figure 1. $\quad 0 \mathrm{~A} \beta_{42}$ causes intracellular accumulation of endogenous cholesterol. $A$, Cholesterol accumulation: basal forebrain and sympathetic neurons were treated with $20 \mu \mathrm{m} \mathrm{oA} \beta_{42}, 20 \mu \mathrm{m}$ revA $\beta_{42}$, or $3 \mu \mathrm{m}$ U18666A for $24 \mathrm{~h}$ in serum-free media. Neuronal cholesterol was detected with filipin staining and confocal microscopy. $\boldsymbol{B}$, Intracellular cholesterol distribution: sympathetic neurons were treated with $20 \mu \mathrm{m} \mathrm{OA} \beta_{42}$ for $24 \mathrm{~h}$. Intracellular localization of cholesterol accumulation was examined by immunofluorescence confocal microscopy using LAMP1 as a marker of late endosome/MVBs, giantin as a Golgi marker, EEA1 as a marker of early endosomes, and COX-IV as mitochondria marker. Filipin was used to detect cholesterol (green pseudo color). Scale bars, $10 \mu \mathrm{m}$.

somes, and partially colocalized with giantin a marker for the Golgi (Fig. $1 B$ ). No evidence of colocalization of cholesterol with EEA1, a marker for early endosomes, or COX-IV, a marker for mitochondria, was observed.

To determine whether the increased filipin fluorescence displayed by oA $\beta_{42}$-treated neurons represented a bona fide increase in cholesterol content, we measured cholesterol mass but we did not detect any significant change induced by oA $\beta_{42}$ (Fig. $2 A$ ). This finding was not surprising because cholesterol mass is not elevated in NPC neurons despite that they sequester cholesterol intracellularly (Karten et al., 2002). The simultaneous occurrence of increased cellular filipin staining with normal cellular cholesterol levels in NPC neurons has been explained by mislocalization of cellular cholesterol attributable to intracellular trafficking dysfunc- tion. Notably, our previous work using neurons cultured in compartmented dishes suggested that $\mathrm{oA} \beta_{42}$-induced apoptosis was attributable in part to decrease in trafficking of survival signals to cell bodies (Song et al., 2006). Therefore, we directly tested the effect of oA $\beta_{42}$ on trafficking in neurons in compartmented cultures (Fig. $2 B)$. We found that intracellular trafficking of cholesterol was significantly reduced in neurons challenged with oA $\beta_{42}$ as it was in U18666A-treated neurons (Fig. $2 C)$. The inhibitory effect of U18666A on axonal transport of endogenous cholesterol had been reported previously (Karten et al., 2003). We also investigated the trafficking of proteins by assessing the retrograde transport of the NGF receptor TrkA, which reaches the cell bodies by vesicular transport. We observed significant decrease in TrkA retrograde trafficking in neurons challenged with oA $\beta_{42}$ (Fig. 2D).

Together, our findings indicate that $\mathrm{oA} \beta_{42}$ inhibits intracellular trafficking and causes sequestration of cholesterol in late endosomes/MVBs and partially at the Golgi.

\section{$\mathrm{A} \beta$ inhibits cholesterol synthesis by interfering with SREBP-2 processing}

Under our experimental conditions, cholesterol sequestered in neurons challenged with oA $\beta_{42}$ derives from endogenous synthesis exclusively, because neurons were cultured in the absence of serum during the treatments with oA $\beta_{42}$. Thus, we attempted to prevent cholesterol accumulation by inhibiting cholesterol synthesis with pravastatin (de Chaves et al., 1997; Saavedra et al., 2007). Contrary to our expectations, cholesterol still accumulated in neurons that received pravastatin with $\mathrm{oA} \beta_{42}$ (Fig. $3 A$ ), despite the effectiveness of pravastatin in reducing cholesterol synthesis (Fig. 3B).

Cellular cholesterol levels are sensed by the pool of cholesterol in the endoplasmic reticulum (ER) (Lange et al., 1999). We rationalized that, because $\mathrm{oA} \beta_{42}$ impairs cholesterol trafficking, oA $\beta_{42}$ could prevent cholesterol transport to the ER, thus increasing cholesterol synthesis. However, we found that oA $\beta_{42}$ significantly reduced cholesterol synthesis in basal forebrain, cortical, and sympathetic neurons (Fig. $3 B$ ). oA $\beta_{42}$ inhibited cholesterol synthesis only at concentrations at which it caused neuronal apoptosis (Fig. $3 C, D$ ), suggesting a link between these two phenomena. However, the lack of significant apoptosis in neurons that received pravastatin (Fig. $3 E$ ) indicates that cholesterol synthesis inhibition is not sufficient to induce apoptosis under our experimental conditions.

Regulation of cholesterol synthesis at the molecular level is mediated by the transcription factor SREBP-2 (Goldstein et al., 2006). For activation, SREBP-2 requires to be transported from 
the ER to the Golgi, in which it undergoes proteolytic cleavage, and the mature form of SREBP-2 translocates into the nucleus (Goldstein et al., 2006). Finding that $\mathrm{oA} \beta_{42}$ inhibited cholesterol synthesis and impaired intracellular trafficking prompted us to examine whether oA $\beta_{42}$ regulates proteolytic activation of SREBP-2. As in other cells, in neurons SREBP-2 cleavage was increased in response to sterol depletion (serum deprivation); however, in the presence of oA $\beta_{42}$, proteolytic activation of SREBP-2 was essentially hindered (Fig. $3 F, G$ ). These results clearly demonstrate that $\mathrm{oA} \beta_{42}$ inhibited SREBP-2 proteolytic cleavage.

\section{$\mathrm{A} \boldsymbol{\beta}$ inhibits protein prenylation}

SREBP-2 controls transcription of all genes of the mevalonate pathway, a biosynthetic pathway for cholesterol and non-steroid isoprenoids farnesyl pyrophosphate and GGPP among others (Horton et al., 2002). Isoprenoids are essential for posttranslational modification of $>100$ proteins (Hooff et al., 2010). Hence, we hypothesized that, by inhibiting the mevalonate pathway, $\mathrm{oA} \beta_{42}$ would affect protein prenylation. We examined prenylation of Rab proteins that regulate vesicular trafficking (Stenmark, 2009). Rab9 and Rab7 reside in late endosomes and participate in vesicular trafficking to late endosome and trans-Golgi (Lombardi et al., 1993; Feng et al., 1995). Rabs require prenylation for membrane targeting and for binding to Rab GDIs. GDIs keep prenylated Rabs in a soluble state in the cytosol and deliver them to proper membrane locations (Pfeffer et al., 1995). To assess the membrane and cytosolic pools of prenylated Rabs, we used two alternative approaches. First, we performed extraction of prenylated proteins with Triton X-114 and found reduced prenylation of Rab9 in oA $\beta_{42}$-treated neurons to an extent similar to prenylation reduction by treatment with geranylgeranyl transferase inhibitor (GGTI-2133) (Fig. 4A). Next, we performed extraction of prenylated proteins with recombinant Rab GDI. The level of prenylated Rab7 extracted from oA $\beta_{42}$-treated neurons was significantly lower than in untreated neurons but was unchanged when neurons were given GGPP together with oA $\beta_{42}$ (Fig. $4 B$ ). GDI capture of prenylated Rabs from cellular membranes may be physically hindered by cholesterol accumulation within membranes (Lebrand et al., 2002; Choudhury et al., 2004; Ganley and Pfeffer, 2006). Thus, to avoid confounding physical effects attributable to the accumulation of cholesterol in neurons treated with oA $\beta_{42}$, we repeated the GDI Rab-capturing experiments in cytosolic and membrane fractions separately and confirmed that protein prenylation is reduced in oA $\beta_{42}$-treated neurons (Fig. 4C,D). To exclude that the inhibition of prenylation by oA $\beta_{42}$ was specific to Rabs, we examined the level of membrane-associated Ras, which is an indication of Ras prenyla-
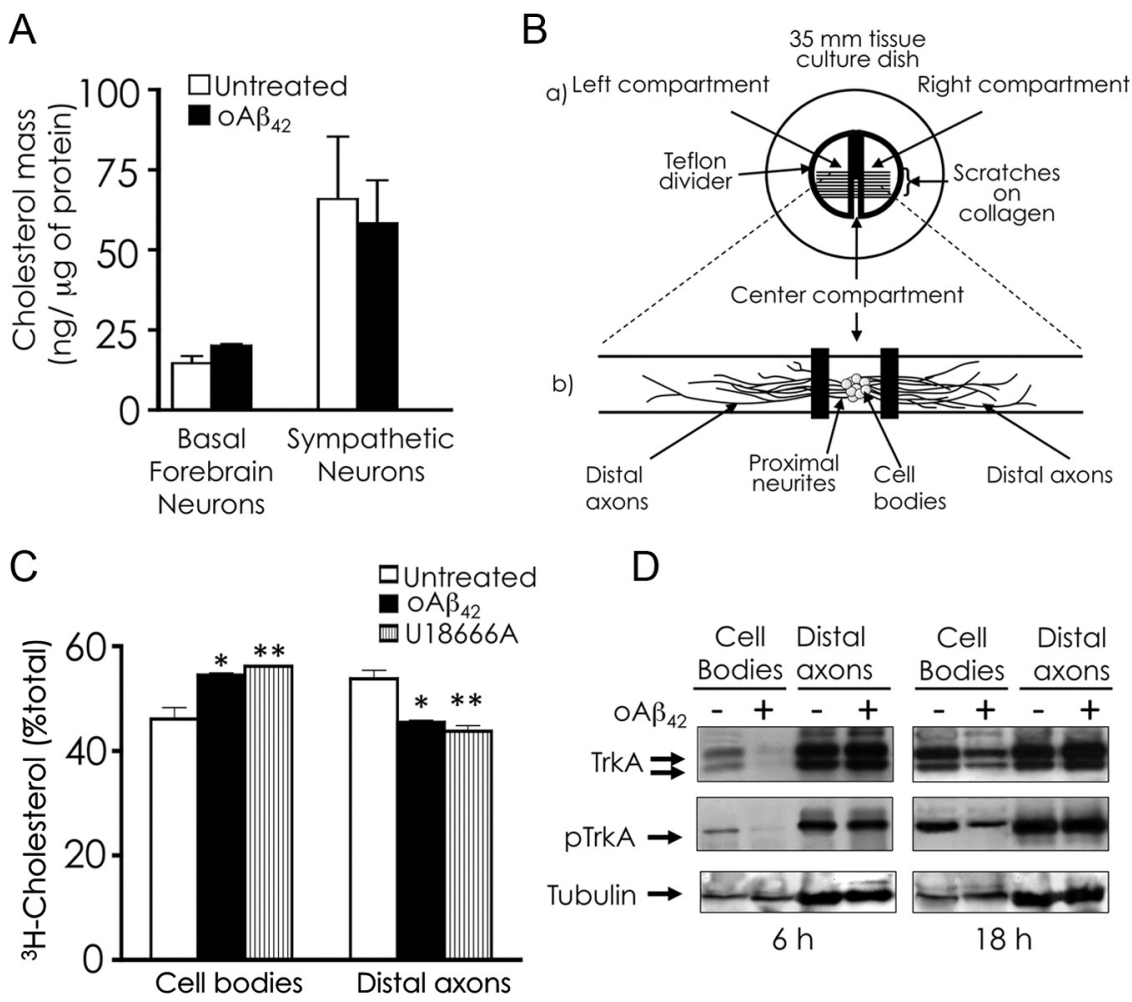

Figure 2. $\quad 0 \mathrm{~A} \beta_{42}$ does not increase cholesterol mass but impairs intracellular trafficking. $A$, Basal forebrain neurons and sympathetic neurons were treated with $20 \mu \mathrm{m} \mathrm{oA} \beta_{42}$ for $24 \mathrm{~h}$ in the absence of serum. Cholesterol mass was measured using Amplex red. $\boldsymbol{B}$, The three-compartment model for culture neurons $(\boldsymbol{a})$ illustrates an entire culture and $(\boldsymbol{b})$ is an enlargement of a single track of a culture in which neurons are plated in the center compartment. Neurites extend under

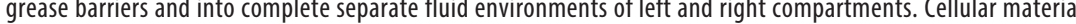
from the center (cell bodies/proximal axons) and side (distal axons) compartments can be harvested and processed arately. C, Cholesterol trafficking. Sympathetic neurons cultured in compartmented dishes were treated with $20 \mu \mathrm{m}$ i . expressed as radioactivity in unesterified cholesterol in distal axons as percentages of total radioactivity present in unesterified cholesterol in cell bodies/proximal neurites + distal axons. Data represent means $\pm S E$ of three independent experiments performed in quintuplicate. ${ }^{*} p<0.05,{ }^{* *} p<0.01$, one-way ANOVA. $\boldsymbol{D}$, Retrograde transport of NGF receptor TrkA. Sympathetic neurons were cultured in three-compartment dishes. Surface axonal proteins were biotinylated in the performed in the presence of $50 \mathrm{ng} / \mathrm{mI} \mathrm{NGF}$. After 6 and $18 \mathrm{~h}$, the material from the cell-body-containing compartment and distal-axon-containing compartment was independently harvested (2 dishes were pooled). Biotinylated proteins were TrkA and activated TrkA (pTrkA) were detected by immunoblot analysis. Non-biotinylated proteins in the supernatant were analyzed by SDS-PAGE and immunoblot analysis for tubulin as loading control. The experiment was repeated twice.

tion. $\mathrm{oA} \beta_{42}$ caused significant decrease of Ras in neuronal membranes, but when neurons received GGPP with oA $\beta_{42}$, membrane Ras levels were unaffected (Fig. $4 E$ ). Although Ras proteins are preferentially modified by farnesylation, geranylgeranylation of KRAS and to a lesser extent NRAS becomes important when farnesylation is blocked (Downward, 2003). Together, these results indicate that $\mathrm{oA} \beta_{42}$ effectively inhibits protein prenylation. The finding that GGPP prevented $A \beta$ inhibition of protein prenylation suggests that the reduction in protein prenylation results from decrease in isoprenoid production. The use of GGPP can be limited by its relative membrane impermeability, but there is documented evidence of GGPP ability to enter cultured cells (Kukar et al., 2005) and to counteract some effects of inhibitors of the mevalonate pathway (Meske et al., 2003; Schulz et al., 2004; Ostrowski et al., 2007). We confirmed GGPP uptake by measuring the incorporation of $\left[{ }^{3} \mathrm{H}\right] \mathrm{GGPP}$ in cel- 
A

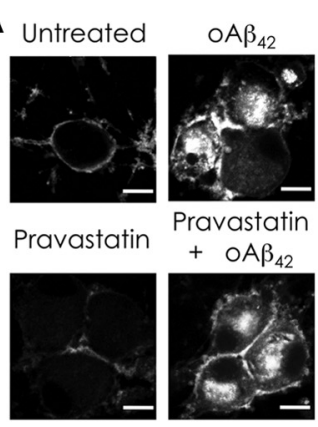

C

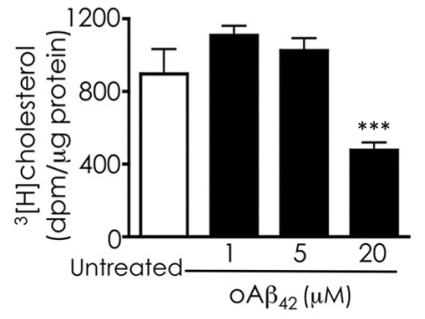

$\mathrm{F}$

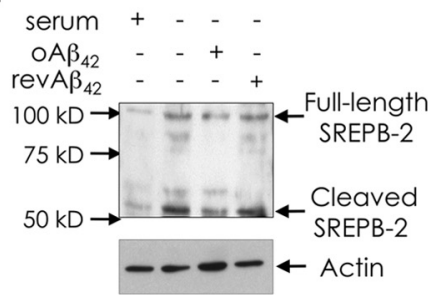

B

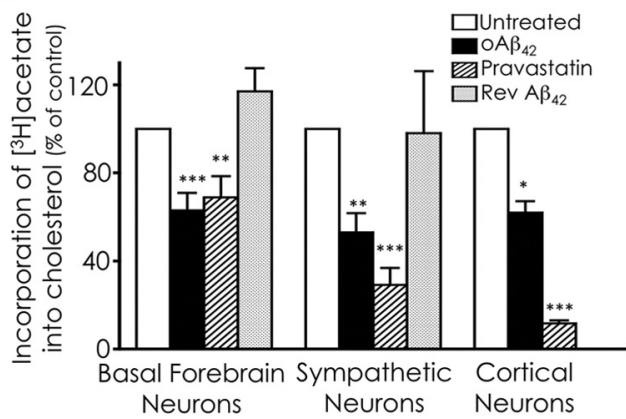

$\mathrm{E}$
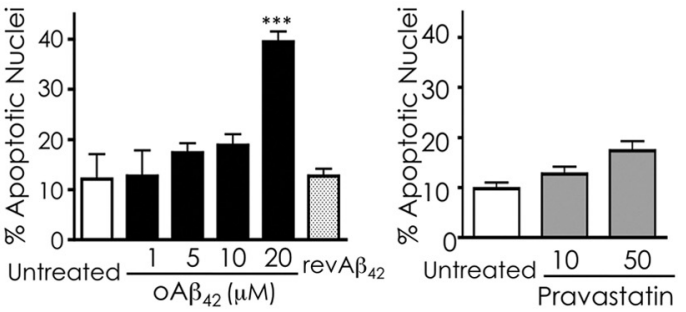

$(\mu \mathrm{M})$

G Cleaved SREBP-2

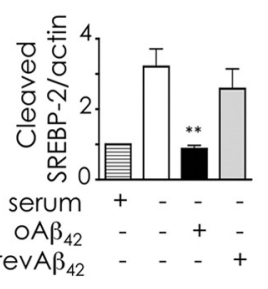

Figure 3. $\quad O A \beta$ inhibits the mevalonate pathway. $A$, Inhibition of cholesterol synthesis does not prevent cholesterol sequestration. Sympathetic neurons were treated with $20 \mu \mathrm{M} 0 \mathrm{~A} \beta_{42}, 50 \mu \mathrm{m}$ pravastatin or $20 \mu \mathrm{m} 0 \mathrm{~A} \beta_{42}$ and $50 \mu \mathrm{m}$ pravastatin for $24 \mathrm{~h}$ in serum-free media. Cholesterol was detected with filipin and examined by confocal microscopy. Scale bars, $10 \mu \mathrm{m} . \boldsymbol{B}, 0 \mathrm{~A} \beta$ inhibits cholesterol synthesis. Basal forebrain, sympathetic, and cortical neurons were treated with $0 \mathrm{~A} \beta_{42}(20 \mu \mathrm{m})$, pravastatin $(50 \mu \mathrm{m})$, or revA $\beta_{42}(20 \mu \mathrm{m})$ for $24 \mathrm{~h}$ (sympathetic and basal forebrain neurons) or $48 \mathrm{~h}$ (cortical neurons). [ $\left.{ }^{3} \mathrm{H}\right] \mathrm{Acetate}(100 \mu \mathrm{Ci} / \mathrm{ml})$ was added for the last $2 \mathrm{~h}$ of treatment. Lipids were extracted and separated by TLC. Incorporation of [ $\left.{ }^{3} \mathrm{H}\right]$ acetate into unesterified cholesterol was calculated as disintegration per minute and per microgram of protein and expressed as percentage of values obtained for untreated neurons. The results are the means \pm SE of three experiments performed in three to five replicates. $C$ Dose-response of $0 A \beta_{42}$ effect on cholesterol synthesis. The same protocol as in $\boldsymbol{B}$ was used. The results are the means \pm SE of three experiments performed in three to five replicates. $D$, Dose-response of $0 A \beta_{42}$-induced apoptosis. Neurons were incubated with different concentrations of $O A \beta_{42}$ or with $20 \mu \mathrm{m} \mathrm{revA} \beta_{42}$. After $36 \mathrm{~h}$, the percentage of apoptotic nuclei was evaluated by Hoechst 33258 staining. Data are expressed as means \pm SE of three experiments. Each experiment was performed in quintuplicate, and 500-1000 neurons per treatment were counted. $\boldsymbol{E}$, Effect of pravastatin on neuronal survival. Neurons were incubated with different concentrations of pravastatin. After $36 \mathrm{~h}$, the percentage of apoptotic nuclei was evaluated by Hoechst 33258 staining. Data are expressed as means \pm SE of three experiments. Each experiment was performed in quintuplicate, and 500 1000 neurons per treatment were counted. $\boldsymbol{F}$, Analysis of SREBP-2 processing. Neurons were incubated as indicated for $24 \mathrm{~h}$, at which time they were harvested and lysed. Proteins were separated by SDS-PAGE, and SREBP-2 was detected by immunoblot analysis of total neuronal lysates. $\mathbf{G}$, Densitometric analysis of SREBP-2 cleavage combining five experiments. Data are means \pm SE. For all experiments, $\left.{ }^{*} p<0.05\right)$, ${ }^{* *} p<0.01$, and ${ }^{* * *} p<0.001$, one-way ANOVA.

lular proteins. Neurons were able to take up $0.2 \pm 0.015 \%$ of the total $\left[{ }^{3} \mathrm{H}\right]$ GGPP added to the medium in $24 \mathrm{~h}$, and $\left[{ }^{3} \mathrm{H}\right] \mathrm{GGPP}$ uptake was not affected by $\mathrm{A} \beta$. However, neurons treated with oA $\beta_{42}$ incorporated twofold to threefold more GGPP in proteins than untreated neurons or neurons treated with pravastatin $(156.94 \mathrm{dpm} /$ actin pixel in oA $\beta$-treated neurons vs $48.51 \mathrm{dpm} /$ actin pixel in untreated neurons and $56.35 \mathrm{dpm} /$ actin pixel in pravastatin-treated neurons). This experiment has two main implications: (1) oA $\beta_{42}$ significantly reduces the endogenous pool of GGPP; and (2) GGPP does not neutralize $\mathrm{oA} \beta_{42}$ effects but truly serves as a substrate for protein prenylation. In addition, these data also show that, under our experimental conditions, pravastatin does not significantly affect iso- prenoids levels, which agrees with the lack of effect of pravastatin on protein prenylation (Fig. 4F) and cell survival (Fig. 3E).

We next investigated whether the decrease in protein prenylation induced by $\mathrm{oA} \beta_{42}$ in cultured neurons was recapitulated in the brain of the TgCRND8 mice overexpressing APP. We found that prenylated pools of Rab7 and Rab9 were reduced in cortex of TgCRND8 mice compared with aged-matched wild-type mice (Fig. 4G,H).

\section{Isoprenoid supply prevents}

$\mathrm{A} \boldsymbol{\beta}$-induced cholesterol sequestration and protects against $\mathbf{A} \boldsymbol{\beta}$-induced neurotoxicity Based on the evidence presented above, we hypothesized that cholesterol sequestration in $\mathrm{oA} \beta_{42}$-treated neurons results from protein prenylation inhibition and could be prevented by GGPP. Supporting this hypothesis, the prenylation inhibitor GGTI caused intracellular cholesterol accumulation similar to treatment with $\mathrm{oA} \beta_{42}$ (Fig. 5A). Administration of GGPP prevented oA $\beta_{42}$-induced, but not GGTIinduced, cholesterol sequestration (Fig. $5 A$ ). Furthermore, GGPP blocked the detrimental effect of $\mathrm{oA} \beta_{42}$ on neuronal metabolic activity (Fig. $5 B$ ) and significantly reduced oA $\beta_{42}$-induced but not GGTIinduced apoptosis (Fig. 5C).

\section{Discussion}

Intracellular cholesterol accumulation Studies in AD brains reported cholesterol accumulation specifically in $\mathrm{A} \beta$ immunopositive neurons (Ohm et al., 2003; Gómez-Ramos and Asunción Morän, 2007; Xiong et al., 2008), and studies in APP/PS1 mouse brains showed that $\mathrm{A} \beta$ accumulation preceded cholesterol accumulation (Fernández et al., 2009). In line with these findings and with the report of increase of free cholesterol caused by $\mathrm{A} \beta_{40}$ in hippocampal neurons (Liu et al., 1998), we show that $\mathrm{A} \beta$ can directly induce intracellular cholesterol sequestration. This is important because a causal relationship between cholesterol sequestration and cell death was identified in NPC (Aqul et al., 2011). NPC and AD present similar endosomal abnormalities, brain accumulation of $\mathrm{A} \beta$ and neurofibrillary tangles, and influence of apolipoprotein $\mathrm{E}$ genotype (Yamazaki et al., 2001; Jin et al., 2004; Koh and Cheung, 2006). These common features and our data suggest that a pathological mechanism involving abnormal cholesterol trafficking could take place in AD. Alternatively, intracellular cholesterol accumulation may be an epiphenomenon of $A \beta$ effects on intracellular trafficking but not a direct cause of neuronal toxicity. Supporting this view, several studies indicated that, depending on the death insult, cells that accumulate cholesterol are not more susceptible to die or they might even survive better (Karten et al., 
2002; Appelqvist et al., 2011; Reiners et al., 2011). However, simultaneous accumulation of cholesterol and $\mathrm{A} \beta_{42}$ in $\mathrm{AD}$ would have more severe consequences to lysosomes than accumulation of cholesterol alone because $\mathrm{A} \beta_{42}$ causes lysosome disruption (Ditaranto et al., 2001; Liu et al., 2010). With respect to the Golgi, the presence of cholesterol in the Golgi of $A \beta$ treated neurons coincides with the intracellular localization of $\mathrm{A} \beta$ in brains of APPxPS1 mouse (Langui et al., 2004) and in astrocytes treated with $\mathrm{A} \beta_{42}$ (Igbavboa et al., 2003, 2009). A $\beta$ accumulation in the Golgi of astrocytes disrupts cholesterol homeostasis (Igbavboa et al., 2003). We are currently investigating whether $A \beta$ localization to the Golgi plays a direct role in inhibition of SREBP-2 cleavage in this organelle.

\section{$\mathrm{A} \boldsymbol{\beta}$ inhibits the mevalonate pathway} $\mathrm{oA} \beta_{42}$-treated neurons do not contain more cholesterol, similar to other cells that sequester cholesterol, such as NPC neurons (Karten et al., 2002) and U18666A-treated neurons (Tashiro et al., 2004). Moreover, we found that $\mathrm{oA} \beta_{42}$ inhibits cholesterol synthesis, which at first seemed paradoxical to the intensive filipin staining. Nevertheless, U18666A, a potent inhibitor of cholesterol synthesis (Runz et al., 2002; Jin et al., 2004), also causes endosomal cholesterol accumulation (Karten et al., 2002; Cenedella, 2009). As for U18666A, the intense filipin staining in $\mathrm{A} \beta$-treated neurons represents impairment in cholesterol trafficking and not net increase in cholesterol.

Inhibition of cholesterol synthesis by $\mathrm{A} \beta_{40}$ but not $\mathrm{A} \beta_{42}$ has been reported previously (Gong et al., 2002; Grimm et al., 2005). The consequences of cholesterol synthesis inhibition in neurons are unclear. Neurons have lower rate of cholesterol synthesis than glia (Nieweg et al., 2009), and in adulthood, neurons might not synthesize cholesterol but outsource cholesterol from astrocytes (Fünfschilling et al., 2007; Aqul et al., 2011), although some studies showed that neurons might maintain some level of cholesterol synthesis (Valdez et al., 2010). Our data suggest that inhibition of cholesterol synthesis per se is not a direct cause of neuronal death because cholesterol synthesis inhibition by pravastatin did not cause neuronal death (de Chaves et al., 1997; Saavedra et al., 2007).

In addition to cholesterol, the mevalonate pathway produces other intermediates, such as isoprenoids, which are required for protein prenylation. We show that Rab and Ras prenylation were significantly reduced in $\mathrm{A} \beta$-treated neurons, and protein prenylation in brain cortex from the TgCRND8 mouse model of AD was significantly lower than in cortex of age-matched wild-type animals. Decreased prenylation in neurons challenged with $\mathrm{A} \beta$
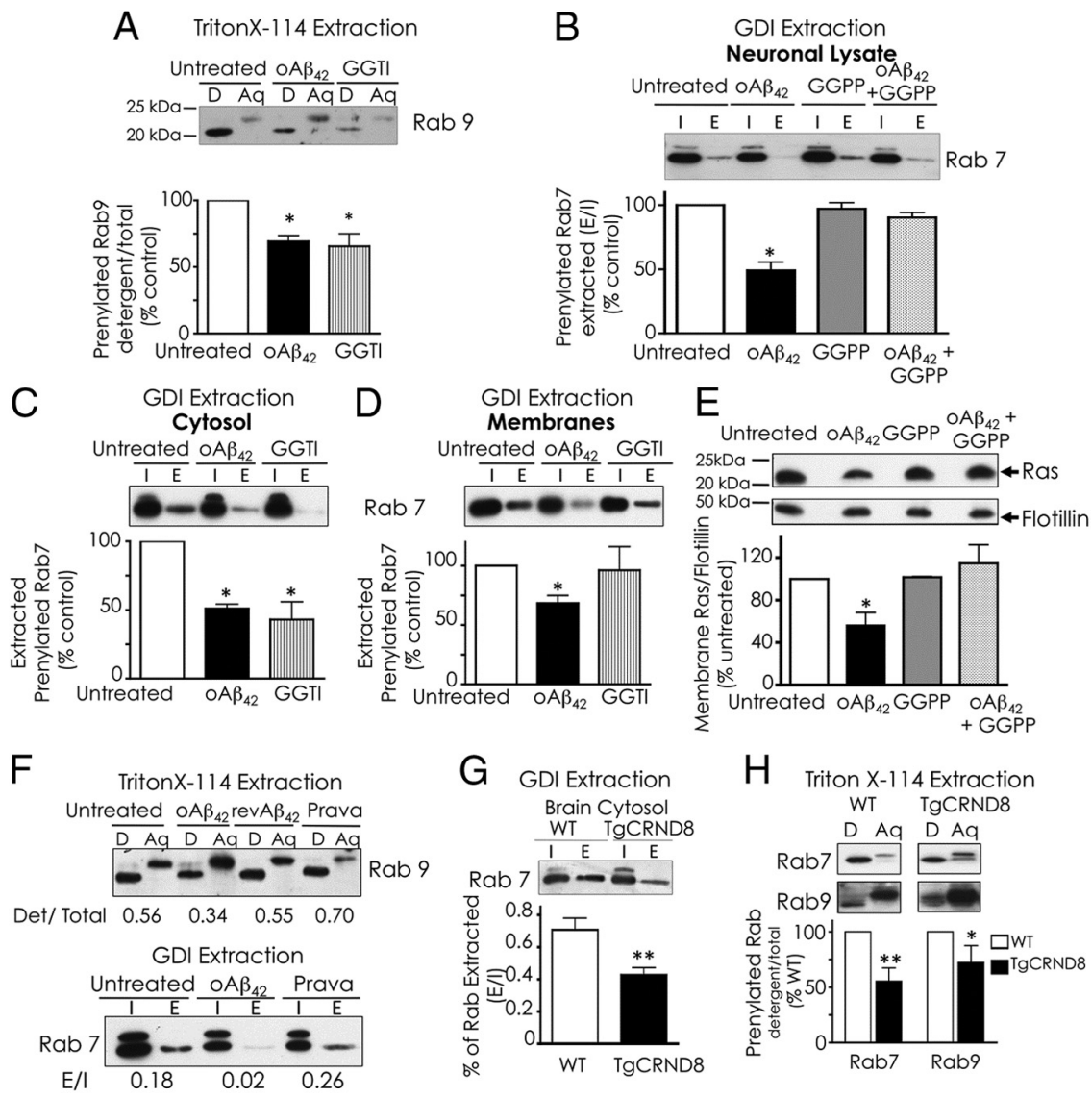

Figure 4. $\quad 0 \mathrm{~A} \beta_{1-42}$ inhibits protein prenylation. Neurons were treated with $20 \mu \mathrm{m} 0 \mathrm{~A} \beta_{42}$ with or without the isoprenoid GGPP $(10 \mu \mathrm{M})$ or with $5 \mu \mathrm{M} \mathrm{GGTI}$ for $24 \mathrm{~h}$. $A$, Analysis of Rab prenylation by extraction with Triton X-114: neuronal lysates (equal amount of protein) were extracted with Triton X-114. Proteins in detergent (D, prenylated proteins) and aqueous (Aq, unprenylated proteins) phases were analyzed by SDS-PAGE and immunoblotting. Ratios between total pixels of Rab9 in detergent/total pixels of Rab 9 in detergent plus aqueous were calculated. The data are presented as percentage control (untreated neurons). Data are means \pm SE of three experiments. $\boldsymbol{B}$, Analysis of Rab prenylation by Rab-GDI capture. Neuronal lysates were prepared. Half sample was used to assess total protein input (I). The other half was used to extract prenylated proteins with recombinant GST-GDI (E). Proteins were analyzed by immunoblot analysis. Ratios between total pixels of Rab7 in GDI-bound (E)/total pixels of Rab7 in (I) were calculated. Densitometric analysis of I included both bands. Data are presented as percentage control (untreated neurons). C, D, GDI capture from cytosol and membranes. Neuronal lysates were fractionated in membranes and cytosol before GST-GDI extraction. Extraction followed the same protocol and considerations as in $\boldsymbol{B}$. $\boldsymbol{E}$, Ras delivery to membranes. 作 analyzed by immunoblotting. Densitometric analysis of Ras/flotillin combined four experiments. Values expressed as percentage of untreated neurons. $\boldsymbol{F}$, Pravastatin does not impair protein prenylation. Sympathetic neurons were treated with $0 \mathrm{~A} \beta_{1-42}(20$ GST-GDI. G, Rab-GDI capture from brains of TgCRND8 mice: brain cortex cytosol fractions were prepared, and prenylated Rabs rated with Triton X-114 from mouse brain cortex homogenates. Densitometric analysis of prenylated (detergent)/prenylated + unprenylated (aqueous) combined results from four brains in each group. In all experiments, data are means \pm SE of values. ${ }^{*} p<$ 0.05 and ${ }^{* *} p<0.01$, one-way ANOVA.

was attributable to shortage of isoprenoids because supply of GGPP prevented prenylation inhibition and cholesterol sequestration, suggesting that normal intracellular trafficking was restored. Inhibition of protein prenylation appears as a pivotal mechanism of neuronal death. GGTI inhibited protein prenylation, caused cholesterol accumulation, and induced neuronal death. GGPP was readily incorporated into prenylated proteins and significantly reduced $\mathrm{A} \beta$-induced neuronal death but, as expected, it could not rescue neurons treated with GGTI.

Isoprenoids and protein prenylation play important roles in the nervous system, especially in AD (Hooff et al., 2010). Reduced isoprenoid production explained the decrease of 
A

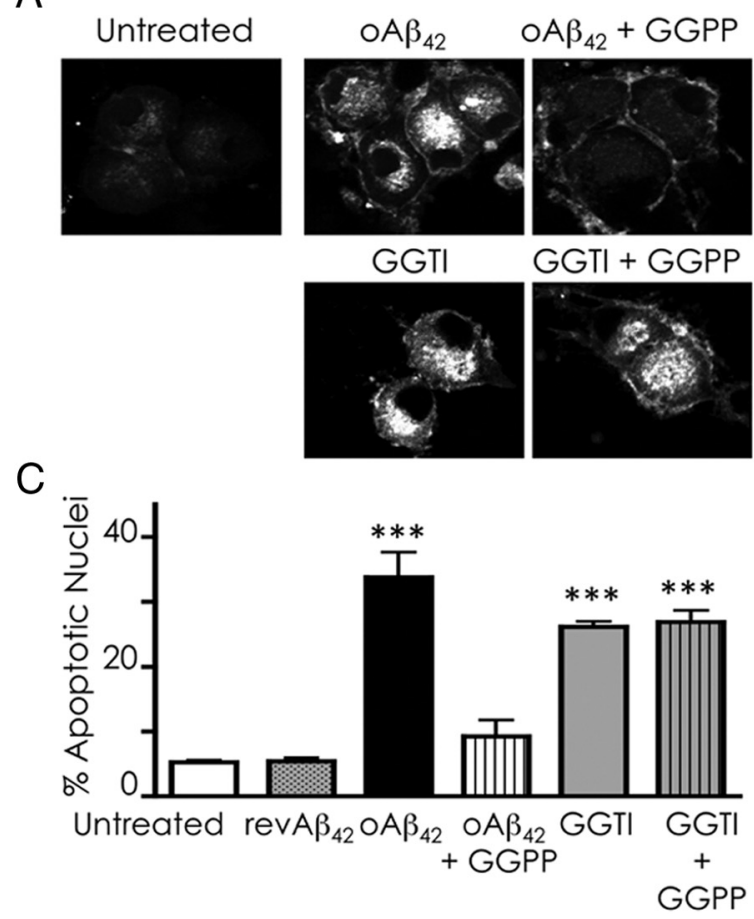

B
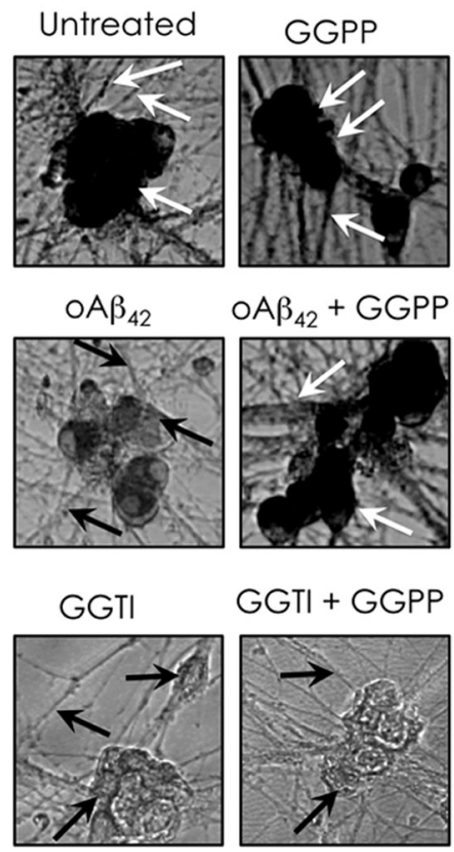

Figure 5. GGPP reduces $0 \mathrm{~A} \beta_{42}$-induced cholesterol sequestration and $0 \mathrm{~A} \beta_{42}$-induced neurotoxicity. Neurons were treated with $20 \mu \mathrm{m} 0 \mathrm{~A} \beta_{42}$ or $5 \mu \mathrm{m} \mathrm{GGTI} \mathrm{with} \mathrm{or} \mathrm{without} 10 \mu \mathrm{m} \mathrm{GGPP}$ for $36 \mathrm{~h}$. $\boldsymbol{A}$, Cholesterol sequestration was detected by filipin staining. $\boldsymbol{B}$, Metabolic activity was examined by MTT assay in situ. White arrows point to healthy cell bodies and neurites containing the formazan compound. Black arrows indicate cell bodies or neurites devoid of the MTT reduction product attributable to reduced metabolic activity. $C$, Apoptosis was quantified by counting nuclei stained with Hoechst 33258. Data are expressed as means \pm SE of three experiments. Each experiment was performed in quintuplicate, and $500-1000$ neurons per treatment were counted. ${ }^{* * *} p<0.001$, one-way ANOVA.

long-term potentiation in hippocampal slices (Matthies et al., 1997; Kotti et al., 2006, 2008), the increase in Tau hyperphosphorylation (Meske et al., 2003), and the prevention of statininduced neurotoxicity by isoprenoids (Tanaka et al., 2000; Meske et al., 2003; Schulz et al., 2004). Protein prenylation is important for APP trafficking and cleavage. Reduction of protein prenylation results in increased or decreased $\mathrm{A} \beta$ production, depending on the cell type (Cole et al., 2005; Ostrowski et al., 2007). Moreover, Ras prenylation reduction represents a mechanism of neurodegeneration (Zipp et al., 2007). In our studies, the decrease in protein prenylation is accompanied by cholesterol accumulation within intracellular membranes, which would favor APP cleavage and A $\beta$ production.

Recent studies showed that GGPP, farnesyl pyrophosphate, and the mRNA of their respective synthases are elevated in $\mathrm{AD}$ brains (Eckert et al., 2009). The significance of this elevation is still unknown because protein prenylation was not examined in this study and elevation of isoprenoids does not warrant an increase in protein prenylation. Our findings suggest that a decrease in isoprenoid synthesis will take place specifically in cells that accumulate $\mathrm{A} \beta$, most likely neurons. Depending on the size of the cell population that contains intracellular $\mathrm{A} \beta$, this might or might not impact the overall content of isoprenoids in the brain. An interesting model has been proposed in which SREBPs in astrocytes are involved in lipid synthesis for supply to neurons for neurite outgrowth, synaptogenesis, and synaptic plasticity $(\mathrm{Ca}-$ margo et al., 2009). According to this model, glia SREBPs may work as control points of neuronal function, providing neurons with appropriate lipids when neurons cannot make their own. Whether astrocytes can supply isoprenoids has not been investigated to our knowledge, but the increase of isoprenoids in $\mathrm{AD}$ brains could represent an astrocytic attempt to compensate a decrease in SREBP-dependent metabolic pathways in neurons.

In addition to the direct effect of $A \beta$ on prenylation, $A \beta$ could also affect indirectly the function of remaining prenylated Rabs by means of cholesterol accumulation within membranes. The level of cholesterol in endocytic compartments plays a role in Rabs fate and function (Lebrand et al., 2002; Choudhury et al., 2004; Ganley and Pfeffer, 2006). GDI capture of prenylated proteins from membranes of $\mathrm{oA} \beta_{42}$-treated neurons is reduced, suggesting that in $\mathrm{A} \beta$-treated neurons there are membrane structural changes similar to those present in NPC cells (Choudhury et al., 2004; Ganley and Pfeffer, 2006). These changes could result from a combination of cholesterol accumulation and the direct interaction of $A \beta$ with cholesterol and other lipids, such as GM1 (Kimura and Yanagisawa, 2007).

Our results indicate that one mechanism of oA $\beta_{42}$ inhibition of the mevalonate pathway is a decrease in SREBP-2 processing. This is different from what has been shown for $A \beta_{40}$. Gong and collaborators found that $\mathrm{A} \beta_{40}$ did not affect SREBP-2 proteolysis (Gong et al., 2002), and Hartmann's group found no inhibition of cholesterol synthesis when mevalonate was used as a precursor, indicating that hydroxy-methyl-glutaryl coenzyme A reductase was the target of $A \beta_{40}$ (Grimm et al., 2005) but also suggesting that $\mathrm{A} \beta_{40}$ does not affect SREBP-2. Importantly, in Gong's and Hartmann's studies, $A \beta$ was used at non-toxic concentrations, and our data indicate that only toxic concentrations of oA $\beta_{42}$ inhibit cholesterol synthesis. We are currently investigating the mechanism(s) of inhibition of SREBP-2 cleavage by oA $\beta_{42}$. We are testing whether $\mathrm{A} \beta$ alters the interaction between SCAP and Insig in the ER, inhibits transport of the complex SREBP-2/SCAP 
to the Golgi (possibly by inhibition of Akt activation), or directly affects SREBP- 2 cleavage by SP1 and SP2 in the Golgi.

\section{Conclusions}

The implications of the identification of SREBP-2 as a target of $\mathrm{oA} \beta_{42}$ could extend beyond the mevalonate pathway and protein prenylation. SREBP-2 is a positive regulator of the transcription factor liver X receptor (LXR), through generation of oxysterol ligands for LXR (Wong et al., 2006). LXR activation positively regulates transcription of the cholesterol efflux gene, ATPbinding cassette transporter $\mathrm{A} 1$ ( $\mathrm{ABCA} 1$ ), among other genes. Our work suggests that $A \beta$ would reduce LXR activation and $\mathrm{ABCA} 1$ transcription. In line with this idea, $\mathrm{A} \beta_{42}$ reduces expression of ABCA1 in an astrocytic cell line, and ABCA1 protein expression is reduced in brain of APP/PS1 mice (Canepa et al., 2011). More importantly, LXR agonists are being regarded as possible therapeutic agents in $\mathrm{AD}$ based on studies in which these agents showed beneficial effects with respect to reduced APP processing into $A \beta$, reduced levels of $A \beta$ peptides, and improved memory function (Hirsch-Reinshagen et al., 2009). Another important gene that would be downregulated by $\mathrm{A} \beta$ inhibition of SREBP-2 cleavage is Dhcr24. The Dhcr24 gene product Seladin-1/DHCR24 is the enzyme that converts desmosterol into cholesterol. Dhcr24 is downregulated in AD brains (Greeve et al., 2000). Seladin-1 is considered neuroprotective because of its anti-apoptotic activity and its involvement in hormonemediated neuroprotection in AD (Peri et al., 2011). Interestingly, Seladin-1 is an LXR target (Wang et al., 2008). Altogether, the available data indicate that reduction of LXR and Seladin-1 are important in AD, but the causes for their downregulation have not been elucidated yet. Our work opens the possibility that $\mathrm{A} \beta$ could regulate Seladin- 1 levels and LXR activation by inhibiting SREBP-2 cleavage.

\section{References}

Appelqvist H, Nilsson C, Garner B, Brown AJ, Kågedal K, Ollinger K (2011) Attenuation of the lysosomal death pathway by lysosomal cholesterol accumulation. Am J Pathol 178:629-639.

Aqul A, Liu B, Ramirez CM, Pieper AA, Estill SJ, Burns DK, Liu B, Repa JJ, Turley SD, Dietschy JM (2011) Unesterified cholesterol accumulation in late endosomes/lysosomes causes neurodegeneration and is prevented by driving cholesterol export from this compartment. J Neurosci 31:9404-9413.

Berridge MV, Tan AS (1993) Characterization of the cellular reduction of 3-(4,5-dimethylthiazol-2-yl)-2,5-diphenyltetrazolium bromide (MTT): subcellular localization, substrate dependence, and involvement of mitochondrial electron transport in MTT reduction. Arch Biochem Biophys 303:474-482.

Billings LM, Oddo S, Green KN, McGaugh JL, LaFerla FM (2005) Intraneuronal Abeta causes the onset of early Alzheimer's disease-related cognitive deficits in transgenic mice. Neuron 45:675-688.

Blanchard V, Moussaoui S, Czech C, Touchet N, Bonici B, Planche M, Canton T, Jedidi I, Gohin M, Wirths O, Bayer TA, Langui D, Duyckaerts C, Tremp G, Pradier L (2003) Time sequence of maturation of dystrophic neurites associated with Abeta deposits in APP/PS1 transgenic mice. Exp Neurol 184:247-263.

Brewer GJ, Torricelli JR (2007) Isolation and culture of adult neurons and neurospheres. Nat Protoc 2:1490-1498.

Camargo N, Smit AB, Verheijen MH (2009) SREBPs: SREBP function in glia-neuron interactions. FEBS J 276:628-636.

Canepa E, Borghi R, Viña J, Traverso N, Gambini J, Domenicotti C, Marinari UM, Poli G, Pronzato MA, Ricciarelli R (2011) Cholesterol and amyloid-beta: evidence for a cross-talk between astrocytes and neuronal cells. J Alzheimers Dis 25:645-653.

Casas C, Sergeant N, Itier JM, Blanchard V, Wirths O, van der Kolk N, Vingtdeux V, van de Steeg E, Ret G, Canton T, Drobecq H, Clark A, Bonici B, Delacourte A, Benavides J, Schmitz C, Tremp G, Bayer TA, Benoit P,
Pradier L (2004) Massive CA1/2 neuronal loss with intraneuronal and $\mathrm{N}$-terminal truncated Abeta42 accumulation in a novel Alzheimer transgenic model. Am J Pathol 165:1289-1300.

Cenedella RJ (2009) Cholesterol synthesis inhibitor U18666A and the role of sterol metabolism and trafficking in numerous pathophysiological processes. Lipids 44:477-487.

Choudhury A, Sharma DK, Marks DL, Pagano RE (2004) Elevated endosomal cholesterol levels in Niemann-Pick cells inhibit rab4 and perturb membrane recycling. Mol Biol Cell 15:4500-4511.

Christensen DZ, Kraus SL, Flohr A, Cotel MC, Wirths O, Bayer TA (2008) Transient intraneuronal A beta rather than extracellular plaque pathology correlates with neuron loss in the frontal cortex of APP/PS1KI mice. Acta Neuropathol 116:647-655.

Christensen DZ, Bayer TA, Wirths O (2010) Intracellular Abeta triggers neuron loss in the cholinergic system of the APP/PS1KI mouse model of Alzheimer's disease. Neurobiol Aging 31:1153-1163.

Chui DH, Dobo E, Makifuchi T, Akiyama H, Kawakatsu S, Petit A, Checler F, Araki W, Takahashi K, Tabira T (2001) Apoptotic neurons in Alzheimer's disease frequently show intracellular Abeta42 labeling. J Alzheimers Dis 3:231-239.

Cole SL, Grudzien A, Manhart IO, Kelly BL, Oakley H, Vassar R (2005) Statins cause intracellular accumulation of amyloid precursor protein, beta-secretase-cleaved fragments, and amyloid beta-peptide via an isoprenoid-dependent mechanism. J Biol Chem 280:18755-18770.

Coxon FP, Ebetino FH, Mules EH, Seabra MC, McKenna CE, Rogers MJ (2005) Phosphonocarboxylate inhibitors of Rab geranylgeranyl transferase disrupt the prenylation and membrane localization of Rab proteins in osteoclasts in vitro and in vivo. Bone 37:349-358.

Dahlgren KN, Manelli AM, Stine WB Jr, Baker LK, Krafft GA, LaDu M) (2002) Oligomeric and fibrillar species of amyloid-beta peptides differentially affect neuronal viability. J Biol Chem 277:32046-32053.

D'Andrea MR, Nagele RG, Wang HY, Peterson PA, Lee DH (2001) Evidence that neurones accumulating amyloid can undergo lysis to form amyloid plaques in Alzheimer's disease. Histopathology 38:120-134.

de Chaves EI, Rusiñol AE, Vance DE, Campenot RB, Vance JE (1997) Role of lipoproteins in the delivery of lipids to axons during axonal regeneration. J Biol Chem 272:30766-30773.

Ditaranto K, Tekirian TL, Yang AJ (2001) Lysosomal membrane damage in soluble Abeta-mediated cell death in Alzheimer's disease. Neurobiol Dis 8:19-31.

Downward J (2003) Targeting RAS signalling pathways in cancer therapy. Nat Rev Cancer 3:11-22.

Eckert GP, Hooff GP, Strandjord DM, Igbavboa U, Volmer DA, Müller WE, Wood WG (2009) Regulation of the brain isoprenoids farnesyl- and geranylgeranylpyrophosphate is altered in male Alzheimer patients. Neurobiol Dis 35:251-257.

Feng Y, Press B, Wandinger-Ness A (1995) Rab 7: an important regulator of late endocytic membrane traffic. J Cell Biol 131:1435-1452.

Fernández A, Llacuna L, Fernández-Checa JC, Colell A (2009) Mitochondrial cholesterol loading exacerbates amyloid $\beta$ peptide-induced inflammation and neurotoxicity. J Neurosci 29:6394-6405.

Folch J, Lees M, Sloane-Stanley GH (1959) A simple method for the isolation and purification of total lipids from animal tissues. J Biol Chem 226:495-509.

Fünfschilling U, Saher G, Xiao L, Möbius W, Nave KA (2007) Survival of adult neurons lacking cholesterol synthesis in vivo. BMC Neurosci 8:1.

Ganley IG, Pfeffer SR (2006) Cholesterol accumulation sequesters Rab9 and disrupts late endosome function in NPC1-deficient cells. J Biol Chem 281:17890-17899.

Goldstein JL, DeBose-Boyd RA, Brown MS (2006) Protein sensors for membrane sterols. Cell 124:35-46.

Gómez-Ramos P, Asunción Morán M (2007) Ultrastructural localization of intraneuronal Abeta-peptide in Alzheimer disease brains. J Alzheimers Dis 11:53-59.

Gong JS, Sawamura N, Zou K, Sakai J, Yanagisawa K, Michikawa M (2002) Amyloid beta-protein affects cholesterol metabolism in cultured neurons: implications for pivotal role of cholesterol in the amyloid cascade. J Neurosci Res 70:438-446.

Greeve I, Hermans-Borgmeyer I, Brellinger C, Kasper D, Gomez-Isla T, Behl C, Levkau B, Nitsch RM (2000) The human DIMINUTO/DWARF1 homolog seladin-1 confers resistance to Alzheimer's disease-associated neurodegeneration and oxidative stress. J Neurosci 20:7345-7352. 
Grimm MO, Grimm HS, Pätzold AJ, Zinser EG, Halonen R, Duering M, Tschäpe JA, De Strooper B, Müller U, Shen J, Hartmann T (2005) Regulation of cholesterol and sphingomyelin metabolism by amyloid-beta and presenilin. Nat Cell Biol 7:1118-1123.

Hirsch-Reinshagen V, Burgess BL, Wellington CL (2009) Why lipids are important for Alzheimer disease? Mol Cell Biochem 326:121-129.

Hooff GP, Wood WG, Müller WE, Eckert GP (2010) Isoprenoids, small GTPases and Alzheimer's disease. Biochim Biophys Acta 1801:896-905.

Horton JD, Goldstein JL, Brown MS (2002) SREBPs: activators of the complete program of cholesterol and fatty acid synthesis in the liver. J Clin Invest 109:1125-1131.

Igbavboa U, Pidcock JM, Johnson LN, Malo TM, Studniski AE, Yu S, Sun GY, Wood WG (2003) Cholesterol distribution in the Golgi complex of DITNC1 astrocytes is differentially altered by fresh and aged amyloid beta-peptide-(1-42). J Biol Chem 278:17150-17157.

Igbavboa U, Sun GY, Weisman GA, He Y, Wood WG (2009) Amyloid betaprotein stimulates trafficking of cholesterol and caveolin-1 from the plasma membrane to the Golgi complex in mouse primary astrocytes. Neuroscience 162:328-338.

Jin LW, Shie FS, Maezawa I, Vincent I, Bird T (2004) Intracellular accumulation of amyloidogenic fragments of amyloid-beta precursor protein in neurons with Niemann-Pick type $C$ defects is associated with endosomal abnormalities. Am J Pathol 164:975-985.

Karten B, Vance DE, Campenot RB, Vance JE (2002) Cholesterol accumulates in cell bodies, but is decreased in distal axons, of Niemann-Pick C1-deficient neurons. J Neurochem 83:1154-1163.

Karten B, Vance DE, Campenot RB, Vance JE (2003) Trafficking of cholesterol from cell bodies to distal axons in Niemann Pick C1-deficient neurons. J Biol Chem 278:4168-4175.

Kimura N, Yanagisawa K (2007) Endosomal accumulation of GM1 ganglioside-bound amyloid beta-protein in neurons of aged monkey brains. Neuroreport 18:1669-1673.

Koh CH, Cheung NS (2006) Cellular mechanism of U18666A-mediated apoptosis in cultured murine cortical neurons: bridging Niemann-Pick disease type C and Alzheimer's disease. Cell Signal 18:1844-1853.

Kotti TJ, Ramirez DM, Pfeiffer BE, Huber KM, Russell DW (2006) Brain cholesterol turnover required for geranylgeraniol production and learning in mice. Proc Natl Acad Sci U S A 103:3869-3874.

Kotti T, Head DD, McKenna CE, Russell DW (2008) Biphasic requirement for geranylgeraniol in hippocampal long-term potentiation. Proc Natl Acad Sci U S A 105:11394-11399.

Kukar T, Murphy MP, Eriksen JL, Sagi SA, Weggen S, Smith TE, Ladd T, Khan MA, Kache R, Beard J, Dodson M, Merit S, Ozols VV, Anastasiadis PZ, Das P, Fauq A, Koo EH, Golde TE (2005) Diverse compounds mimic Alzheimer disease-causing mutations by augmenting Abeta42 production. Nat Med 11:545-550.

LaFerla FM, Tinkle BT, Bieberich CJ, Haudenschild CC, Jay G (1995) The Alzheimer's A beta peptide induces neurodegeneration and apoptotic cell death in transgenic mice. Nat Genet 9:21-30.

Lange Y, Ye J, Rigney M, Steck TL (1999) Regulation of endoplasmic reticulum cholesterol by plasma membrane cholesterol. J Lipid Res 40:2264-2270.

Langui D, Girardot N, El Hachimi KH, Allinquant B, Blanchard V, Pradier L, Duyckaerts C (2004) Subcellular topography of neuronal Abeta peptide in APPxPS1 transgenic mice. Am J Pathol 165:1465-1477.

Lebrand C, Corti M, Goodson H, Cosson P, Cavalli V, Mayran N, Faur é J, Gruenberg J (2002) Late endosome motility depends on lipids via the small GTPase Rab7. EMBO J 21:1289-1300.

Liu JP, Tang Y, Zhou S, Toh BH, McLean C, Li H (2010) Cholesterol involvement in the pathogenesis of neurodegenerative diseases. Mol Cell Neurosci 43:33-42.

Liu Y, Peterson DA, Schubert D (1998) Amyloid beta peptide alters intracellular vesicle trafficking and cholesterol homeostasis. Proc Natl Acad Sci U S A 95:13266-13271.

Lombardi D, Soldati T, Riederer MA, Goda Y, Zerial M, Pfeffer SR (1993) Rab9 functions in transport between late endosomes and the trans Golgi network. EMBO J 12:677-682.

Matthies H Jr, Schulz S, Hollt V, Krug M (1997) Inhibition by compactin demonstrates a requirement of isoprenoid metabolism for long-term potentiation in rat hippocampal slices. Neuroscience 79:341-346.

Meske V, Albert F, Richter D, Schwarze J, Ohm TG (2003) Blockade of HMG-CoA reductase activity causes changes in microtubule-stabilizing protein tau via suppression of geranylgeranylpyrophosphate formation: implications for Alzheimer's disease. Eur J Neurosci 17:93-102.

Narita K, Choudhury A, Dobrenis K, Sharma DK, Holicky EL, Marks DL, Walkley SU, Pagano RE (2005) Protein transduction of Rab9 in Niemann-Pick C cells reduces cholesterol storage. FASEB J 19:1558 1560.

Nieweg K, Schaller H, Pfrieger FW (2009) Marked differences in cholesterol synthesis between neurons and glial cells from postnatal rats. J Neurochem 109:125-134.

Nixon RA (2005) Endosome function and dysfunction in Alzheimer's disease and other neurodegenerative diseases. Neurobiol Aging 26:373-382.

Oddo S, Caccamo A, Shepherd JD, Murphy MP, Golde TE, Kayed R, Metherate R, Mattson MP, Akbari Y, LaFerla FM (2003) Triple-transgenic model of Alzheimer's disease with plaques and tangles: intracellular Abeta and synaptic dysfunction. Neuron 39:409-421.

Ohm TG, Treiber-Held S, Distl R, Glockner F, Schonheit B, Tamanai M, Meske V (2003) Cholesterol and tau protein-findings in Alzheimer's and Niemann Pick C's disease. Pharmacopsychiatry 36 [Suppl 2]:S120-S126.

Ostrowski SM, Wilkinson BL, Golde TE, Landreth G (2007) Statins reduce amyloid-beta production through inhibition of protein isoprenylation. J Biol Chem 282:26832-26844.

Peri A, Benvenuti S, Luciani P, Deledda C, Cellai I (2011) Membrane cholesterol as a mediator of the neuroprotective effects of estrogens. Neuroscience 191:107-117.

Pfeffer SR, Dirac-Svejstrup AB, Soldati T (1995) Rab GDP dissociation inhibitor: putting rab GTPases in the right place. J Biol Chem 270:17057-17059.

Reiners JJ Jr, Kleinman M, Kessel D, Mathieu PA, Caruso JA (2011) Nonesterified cholesterol content of lysosomes modulates susceptibility to oxidant-induced permeabilization. Free Radic Biol Med 50:281-294.

Runz H, Rietdorf J, Tomic I, de Bernard M, Beyreuther K, Pepperkok R, Hartmann T (2002) Inhibition of intracellular cholesterol transport alters presenilin localization and amyloid precursor protein processing in neuronal cells. J Neurosci 22:1679-1689.

Saavedra L, Mohamed A, Ma V, Kar S, de Chaves EP (2007) Internalization of beta-amyloid peptide by primary neurons in the absence of apolipoprotein E. J Biol Chem 282:35722-35732.

Saito Y, Suzuki K, Nanba E, Yamamoto T, Ohno K, Murayama S (2002) Niemann-Pick type C disease: accelerated neurofibrillary tangle formation and amyloid beta deposition associated with apolipoprotein E epsilon 4 homozygosity. Ann Neurol 52:351-355.

Schulz JG, Bösel J, Stoeckel M, Megow D, Dirnagl U, Endres M (2004) HMG-CoA reductase inhibition causes neurite loss by interfering with geranylgeranylpyrophosphate synthesis. J Neurochem 89:24-32.

Selkoe DJ (2004) Alzheimer disease: mechanistic understanding predicts novel therapies. Ann Intern Med 140:627-638.

Song MS, Saavedra L, de Chaves EI (2006) Apoptosis is secondary to nonapoptotic axonal degeneration in neurons exposed to Abeta in distal axons. Neurobiol Aging 27:1224-1238.

Stenmark H (2009) Rab GTPases as coordinators of vesicle traffic. Nat Rev Mol Cell Biol 10:513-525.

Takahashi RH, Milner TA, Li F, Nam EE, Edgar MA, Yamaguchi H, Beal MF, $\mathrm{Xu} \mathrm{H}$, Greengard P, Gouras GK (2002) Intraneuronal Alzheimer abeta42 accumulates in multivesicular bodies and is associated with synaptic pathology. Am J Pathol 161:1869-1879.

Tanaka T, Tatsuno I, Uchida D, Moroo I, Morio H, Nakamura S, Noguchi Y, Yasuda T, Kitagawa M, Saito Y, Hirai A (2000) Geranylgeranylpyrophosphate, an isoprenoid of mevalonate cascade, is a critical compound for rat primary cultured cortical neurons to protect the cell death induced by 3-hydroxy-3-methylglutaryl-CoA reductase inhibition. J Neurosci 20:2852-2859.

Tashiro Y, Yamazaki T, Shimada Y, Ohno-Iwashita Y, Okamoto K (2004) Axon-dominant localization of cell-surface cholesterol in cultured hippocampal neurons and its disappearance in Niemann-Pick type $\mathrm{C}$ model cells. Eur J Neurosci 20:2015-2021.

Tomiyama T, Matsuyama S, Iso H, Umeda T, Takuma H, Ohnishi K, Ishibashi K, Teraoka R, Sakama N, Yamashita T, Nishitsuji K, Ito K, Shimada H, Lambert MP, Klein WL, Mori H (2010) A mouse model of amyloid $\beta$ oligomers: their contribution to synaptic alteration, abnormal tau phosphorylation, glial activation, and neuronal loss in vivo. J Neurosci 30:4845-4856. 
Valdez CM, Smith MA, Perry G, Phelix CF, Santamaria F (2010) Cholesterol homeostasis markers are localized to mouse hippocampal pyramidal and granule layers. Hippocampus 20:902-905.

Wang Y, Rogers PM, Stayrook KR, Su C, Varga G, Shen Q, Nagpal S, Burris TP (2008) The selective Alzheimer's disease indicator-1 gene (Seladin-1/ DHCR24) is a liver X receptor target gene. Mol Pharmacol 74: 1716-1721.

Wirths O, Multhaup G, Czech C, Feldmann N, Blanchard V, Tremp G, Beyreuther K, Pradier L, Bayer TA (2002) Intraneuronal APP/A beta trafficking and plaque formation in beta-amyloid precursor protein and presenilin-1 transgenic mice. Brain Pathol 12:275-286.

Wong J, Quinn CM, Brown AJ (2006) SREBP-2 positively regulates transcription of the cholesterol efflux gene, ABCA1, by generating oxysterol ligands for LXR. Biochem J 400:485-491.
Xiong H, Callaghan D, Jones A, Walker DG, Lue LF, Beach TG, Sue LI, Woulfe J, Xu H, Stanimirovic DB, Zhang W (2008) Cholesterol retention in Alzheimer's brain is responsible for high beta- and gammasecretase activities and Abeta production. Neurobiol Dis 29:422-437.

Yamazaki T, Chang TY, Haass C, Ihara Y (2001) Accumulation and aggregation of amyloid beta-protein in late endosomes of Niemann-pick type $\mathrm{C}$ cells. J Biol Chem 276:4454-4460.

Zhang Y, McLaughlin R, Goodyer C, LeBlanc A (2002) Selective cytotoxicity of intracellular amyloid beta peptide1-42 through p53 and Bax in cultured primary human neurons. J Cell Biol 156:519-529.

Zipp F, Waiczies S, Aktas O, Neuhaus O, Hemmer B, Schraven B, Nitsch R, Hartung HP (2007) Impact of HMG-CoA reductase inhibition on brain pathology. Trends Pharmacol Sci 28:342-349. 